\title{
SOME THOUGHTS ON BRIDEWEALTH IN SOUTH AFRICA AND DOWRY IN ROMAN LAW
}

\author{
DOI:10.24193/SUBBiur.62(2017).4.5 \\ Published Online: 2017-12-20 \\ Published Print: 2017-12-30
}

\section{Gardiol van NIEKERK*}

\begin{abstract}
Bridewealth still forms part of the indigenous South African marriage culture. Legislative recognition of African customary marriages stripped them of many of their characteristic indigenous African features that offered protection to African women and children. This article focuses on the role of bridewealth in the formation of a valid customary marriage, and in the maintenance of the wife and her children should the need arise. The hypothesis is considered that the Roman law of dowry can provide new perspectives on the problem areas of bridewealth in African customary law. Even though principally opposites, there are numerous similarities in the role and function of bridewealth in African marriage culture and of dowry in Roman society.
\end{abstract}

Keywords: bridewealth; dowry; African customary law; customary marriage; civil marriage; Roman marriage; legal requirements for marriage; maintenance; recovery of dowry/bridewealth.

\section{Introduction}

The handing over marriage goods or bridewealth to the family of the bride in anticipation of (or subsequent to) a marriage today still forms an integral part of indigenous African cultures. So important is the institution in the living African customary marriage laws in current-day South Africa, that bridewealth also forms part of the majority of African civil marriages.

Due to the prevailing legal pluralism in South Africa, African customary law was historically regarded as a secondary legal system with limited application. The Roman-Dutch common law applied as the primary legal system and formed the core of South African law. Customary marriages were not recognised as marriages because they were potentially polygynous and because the transfer of bridewealth was an essential feature of such marriages, both being regarded as against Christian morals. Colonial administrators saw the bridewealth custom as the purchasing of a wife, notwithstanding its evident spiritual significance in indigenous African culture. ${ }^{1}$ This prejudice against African marriages persisted 
until the late twentieth century and crucially affected the personal lives of a large section of South African society, especially women and children.

However, today the Constitution of the Republic of South Africa, 1996, officially recognises African customary law. In terms of section 211(3), all courts "must apply customary law when that law is applicable, subject to the Constitution and any legislation that specifically deals with customary law". In theory, the implication of this change was that within a paradigm of state-law pluralism, ${ }^{2}$ both western or European common law and African customary law should apply as independent parallel legal systems. In reality, though, South African law is still predominantly Roman-Dutch law ${ }^{3}$ and the courts still struggle to figure out what exactly to do with customary law. The prevailing sentiment appears to be that customary law must somehow be incorporated into the western/ European common law.

The constitutional recognition of African customary law had far-reaching effects on customary marriages. It set in motion an investigation by the South African Law Reform Commission ${ }^{4}$ into the harmonisation of civil law and customary law marriages. ${ }^{5}$ This investigation resulted in the promulgation of the Recognition of Customary Marriages Act, ${ }^{6}$ which formally recognised African customary marriages as lawful marriages. The Act legalised polygyny to a limited extent ${ }^{7}$ and, indirectly at least, retained the custom of bridewealth.

The uniform recognition of customary marriages was widely welcomed. In many respects, it offered protection to African women and children, but through its regulation of customary marriages, it caused numerous uncertainties that had the opposite effect. Bar the recognition of polygyny, the legislative regulation of customary marriages stripped them of most of their characteristic indigenous African features. As a result, the status of customary marriages is still shrouded in uncertainty in South African law despite their official recognition. Polygyny and bridewealth are the main problem areas. Against this backdrop, I will focus on bridewealth, and more specifically its role in the formation of a valid customary marriage and its maintenance function.

At a conference on "Law in Africa: New perspectives on origins, foundations and transition", it was observed that there is an uncanny likeness in the social development of customary marriages in present-day South Africa and in Roman society. The authors considered the hypothesis that Roman law principles could shed light on certain problems relating to bridewealth. ${ }^{8}$ The question arises whether the Roman law experience could provide new perspectives on the specific problem areas of bridewealth in African customary law that I alluded to earlier. I will attempt to find some solutions by analogy with the Roman law of marriage and the institution of dowry. ${ }^{9}$

Prima facie, it may appear incongruous to compare the Roman institution of dowry with the indigenous institution of bridewealth given that in essence dowry is the reverse of bridewealth. ${ }^{10}$ Bridewealth is transferred by the prospective husband to the family of the bride, whereas dowry is transferred from the side of the bride to that of the groom. Nevertheless, one may find surprising similarities in the underlying values of these two ancient legal systems, if not in the relevant legal rules themselves. Among others, there appears to be fundamental parallels in the function of these institutions, and there are 
similarities in certain rules determining rights of retention when the marriage fails and in the link between dowry and bridewealth and procreation.

\section{Bridewealth: its meaning in African marriage culture}

There is much controversy regarding the meaning and function of bridewealth. From a functionalist, typical legal perspective, using known western/ European legal precepts and principles as analytical tools, it may be said that marriage in African customary law displays features of a contract. It is an agreement between two families that the marital authority over the woman, which includes rights to her reproductive capacity and service as well as her earnings, will be transferred to the husband's family. ${ }^{11}$ Delivery of bridewealth, which is transferred in ownership to the woman's family, ${ }^{12}$ is the counter performance in terms of this bilateral real contract. ${ }^{13}$

The object of transferring the limited authority over the woman is to establish and maintain a family. This aligns with the purpose of marriage: to have children and to ensure the continued existence of the family group. African law shares this goal of procreation in marriage with numerous societies, old and modern, including Roman society. ${ }^{14}$ In Roman culture, the primary objective of marriage was to beget children and the connection between marriage and procreation was linked to natural law. Thus, in the first book of the Digest, in his definition of natural law, Ulpian stated: "Jus naturale is that which nature has taught to all animals; for it is not a law specific to mankind ... Out of this comes the union of man and woman which we call marriage, and the procreation of children, and their rearing..."15 Augustus reinforced the ethos of procreation in marriage in his notorious marriage legislation, which encouraged childbearing to increase the population. ${ }^{16}$ It is significant that also in Roman law a clear connection was made between the dowry and procreation. Pomponius's text in D. 24.3.1 confirms the interconnection of marriage, dowry and procreation: "An action for the dowry takes precedence at all times and in all circumstances; for it is in the public interest for women to keep their dowries, since it is absolutely essential for women to have dowries so that they can produce offspring and replenish the state with their children." ${ }^{17}$

But, interpreting the transfer of bridewealth in African law as counter performance in terms of a bilateral, real contract, which obligates the prospective bride's family of origin to transfer her to the family of the prospective husband, bears the risk that the institution of bridewealth may be regarded as a mere economic institution. ${ }^{18}$ Such an interpretation inevitably leads to the bride being viewed as an economic entity that is sold to her husband's family. ${ }^{19}$ It may further create the impression that the transfer of bridewealth is a necessary requirement for a valid customary marriage. A misinterpretation of this kind typically results when western/ European legal principles are used to explain African law: the African institution is distorted by trying to force it into a preconceived "western" paradigm. Bearing this caveat mind, there is another way of explaining the dowry agreement in African law, namely with reference to the dictio dotis in Roman law, the formal verbal contract, in which 
the bride or her ascendants promised to give dowry to the husband.$^{20}$ Interpreted this way, the bridewealth agreement may be seen as a unilateral contract, reducing the risk of viewing the prospective bride as a chattel.

Ultimately though, the institution of bridewealth is a multi-faceted social institution and not merely part of a contract. In African marriage culture, the institution of handing over marriage goods to the family of the bride has magico-religious significance. It is considered as a token of gratitude to the woman's group for having raised her and as compensation for separating the woman from her family, and aimed at strengthening the bond with her new family and ensuring that the ancestors make her fertile. Bridewealth is a spiritual and social symbol of the bond between the respective families. ${ }^{21}$ It is a means to restore equilibrium in the bride's family (disturbed by the transfer of the woman) and a means of maintaining equilibrium in the relationship between the living members of her family group and the deceased ancestors. ${ }^{22}$ Participants in the South African Law Reform Commission's investigation of customary marriages held strong views about the institution. Many objected to the use of the word "bridewealth" because they felt that "it could not do conceptual justice" to the customary institution which they regarded as a "blood contract, a mandatory and imperative sine qua non condition for any marriage in indigenous African communities". 23

The high esteem in which bridewealth is held today has been confirmed in empirical studies. A study conducted in the late 1990s, for example, touched upon the question of the general attitude towards the institution of bridewealth as well as the extent to which bridewealth determined a wife's status within a family group. The conclusion drawn in the study, from information elicited by means of questionnaires, was that bridewealth was then still highly regarded, even in urban areas and among participants who had assumed a western lifestyle. More than 70 per cent of the interviewees still conformed to the traditional view that women with bridewealth held a far more honoured position than those without. ${ }^{24}$

Likewise, more than a decade later, in a study conducted among the Zulu, the connection between bridewealth and honour clearly came to the fore. ${ }^{25}$ The researchers in that study concluded from their investigation that there was an inextricable link between bridewealth and respect. According to the majority of the interviewees, bridewealth conferred "dignity on their position as a wife". ${ }^{26}$ They found that the link between bridewealth and respect or honour encompassed the following: for both the husband and wife it signified respect for their culture, respect towards each other, their parents, the extended family, the community, and their ancestors. In turn, the woman for whom the bridewealth was transferred gained the respect of her new family and the community. She owed respect to her husband, his and her own family, the community and especially towards her in-laws. ${ }^{27}$ Importantly, bridewealth distinguished the customary marriage from an informal sexual relationship.

From this, one should not assume that customary marriages without bridewealth were possible in the past or is prevalent today. In traditional societies, bridewealth formed part of all marriages, whether actually then transferred, or merely just negotiated. Recent research among the Zulu established that even though bridewealth is not a legal requirement 
for a valid marriage, it still forms part of most civil (or double ${ }^{28}$ ) marriages and that all customary marriages involve bridewealth. ${ }^{29}$ The two studies referred to above, were conducted in modern-day societies and civil marriages formed part of the interviewees' frame of reference. There was no indication in the studies among the Zulu what type of marriages the respondents were in, but in the study in Atteridgeville and Mamelodi, by far the majority of the married participants were in civil-law marriages or in double marriages. Moreover, bridewealth had been given or negotiated in more than 90 per cent of their civil and the double marriages and in 100 per cent of their customary marriages. ${ }^{30}$

Therefore, one may assume that for customary marriages, the special place of honour stemmed from the fact that the woman was married, rather than from the fact that bridewealth had been transferred. The same probably applies to the civil and double marriages. Interestingly, the investigation among the Zulu confirmed the traditional cultural view that "married women ... command far greater respect than unmarried women in Zulu society". ${ }^{31}$ The researchers in the Zulu study concluded, "a female only becomes a "woman" by being lobola'd [by bridewealth being transferred] and married. High levels of respect for tradition, cultural pride and the wish to live a dignified life are significant elements of Zulu womanhood."32

The honoured position of the wife (with bridewealth) in African law reminds of the Roman matrona's unique position of respect in Roman society. In the same way, bridewealth elevates a sexual relationship between a man and woman to a marriage in African society, dowry was an indication that there was a valid Roman marriage with a freeborn woman; that the parties intended to be married and not to live in concubinage. Even though a marriage could exist without a dowry, the opposite was not possible. ${ }^{33}$ Honour, dignity, modesty, prudence and chastity ${ }^{34}$ were the attributes of the married woman and eventually became the benchmark of honeste vivere for women generally. ${ }^{35}$ Interestingly, Treggiari, ${ }^{36}$ relying on Plautus, ${ }^{37}$ draws a connection between the dowry and respectability, observing that, "marriage without dowry was undesirable and disreputable". Indeed, a concubine was a woman (usually of lower social standing who was not eligible for marriage) in a long-term sexual relationship with a man. Among the persons who were not eligible for marriage were slaves, actors, innkeepers or prostitutes, or someone related to them. ${ }^{38}$ The prohibition of marriages on social grounds was underscored by the principle that a person of rank was not permitted to marry a person who lived dishonourably, or was related to such a person. ${ }^{39}$

As noted, in trying to find common ground in different legal systems there is always a risk of forcing legal principles and institutions of the one system into the pre-conceived cultural stereotype of the other system. It is therefore prudent to take note of another possible interpretation of the special status of the Roman matrona with a dowry: the Roman uxor dotata's distinctive status may be attributed to the power she had over her husband, rather than to her honourable attributes. A large dowry was held to be a "powerful lever" that ensured that, irrespective of her legal status, the wife was never really in her husband's control. ${ }^{40}$ The dowry, especially a large one, independence of property, and her right to divorce secured potential power and independence for a wife. She could leave or threaten 
to leave her husband in the knowledge that the dowry would have to be returned, at least partially. ${ }^{41}$

\section{Bridewealth and maintenance}

In the African law, one of the obligations that flows from the marriage is the maintenance of the woman and her offspring. Bridewealth served as security that she and her children would be properly cared for during or after the marriage. Bridewealth therefore safeguarded that the bride's family of origin would take care of her should the marriage fail or she be mistreated, and, conversely, it guaranteed that her husband and his family would treat her well during the subsistence of the marriage. ${ }^{42}$ If treated badly, the wife and her children could return to her group of origin and remain there until relations could be mended. If the marital relationship ended because she and her children had not received proper care, the husband forfeited the marriage goods. Her family was then obliged to take care of them and they could use the bridewealth to this end. ${ }^{43}$

Nowadays, though, the traditional maintenance function of bridewealth has changed. In a prevailing capitalist economy, cash and consumer goods have replaced traditional marriage goods such as cattle. Concomitantly, the amount of bridewealth has increased and there appears to be a trend to commercialise the institution. ${ }^{44}$ Families use the bridewealth for their own benefit and regard it as quid pro quo for the costs incurred in raising the bride. ${ }^{45}$ The result is that the wife's family of origin is often loathe taking care of her and her children in case of need. ${ }^{46}$

Some two decades ago it was stated in published research that " $\mathrm{t}] \mathrm{h}$ he maintenance character of lobolo [bridewealth] as in traditional customary family law should be revived". ${ }^{7}$ Interestingly, there the focus was on the interests of the husband, and not as is customary, on those of the wife. The premise was that because the traditional role of bridewealth had fallen by the wayside, the husband now finds himself in an untenable position upon divorce: In terms of the Recognition of Customary Marriages Act, only a court of law may dissolve a customary marriage. ${ }^{48}$ As a rule, the courts grant custody to the mother and hold the father responsible for maintenance of the children and his former wife despite the fact that he had previously transferred bridewealth and that the woman's family of origin should be responsibility for their care or should at least share the responsibility. However, one cannot ignore the fact that maintenance orders are notoriously ignored, and that this leaves the woman and her children without any recourse. For example, empirical research in Cape Town has shown that on average 85 per cent of fathers default on maintenance orders. ${ }^{49}$

Today the customary marriage is neither an African nor a civil-law marriage. It has become a hybrid with features of both civil and customary marriages, which deprives the wife of the protection she might have had under customary law when the marriage is dissolved. The Recognition of Customary Marriages Act $^{50}$ empowers a court that grants a decree of divorce to take into consideration the rules of customary law when it makes an 
order for the payment of maintenance. This section arguably enables the courts to make the family to whom the bridewealth was transferred, at least partially responsible for the maintenance of the woman and her children. ${ }^{51}$

In Roman law, there was a similar connection between dowry and maintenance. The Roman rules relating to dowry in this regard provide an interesting perspective on the maintenance problems experienced in African customary law. An important purpose of the Roman dowry was the maintenance of the wife and her children. The liberum matrimonium ${ }^{52}$ and the concomitant independence of property meant that the husband was responsible for the maintenance of his wife and children, a burden alleviated by the dowry. The dowry agreement was usually concluded before the marriage took place. The bride or her family transferred, or promised to transfer, property of a monetary value to the husband who obtained ownership of the dowry, subject to some restrictions. ${ }^{53}$ In the late Republic, the wife had the actio rei uxoriae for the recovery of the dowry, ${ }^{54}$ irrespective of whether there had been a prior agreement about its fate when the marriage broke down.

A decree issued in 439 confirmed the importance of dowry in the maintenance of the children when it determined that upon the death of the wife, the dowry had to go to the children she had with her husband, and should not revert to the person who provided the dowry. ${ }^{55}$ The husband's rights in the dowry became increasingly limited, and under Justinian his ownership existed merely in name. Thus, Tryphoninus in D. 23.2.75 remarked, "[a]lthough the dowry becomes a part of the property of the husband, it nevertheless, in fact, belongs to the wife".

It appears as if the maintenance of the wife had become the central purpose of the dowry by the time of Justinian. ${ }^{56}$ The rules relating to the return of the dowry when the marriage ended confirm the maintenance function of this institution ${ }^{57}$ and remind of the maintenance function of bridewealth in traditional African customary law. ${ }^{58}$ As a rule, the dowry reverted to the wife or her family when the marriage was dissolved. If there was no prior agreement, the dowry was returned but the husband retained a portion because he remained responsible for the support of the children. Upon divorce, an additional fraction was retained as a penalty for the wife's misbehaviour, if any. An agreement about the dowry, which was often preceded by extended negotiations, was usually reduced to writing to avoid uncertainty about what exactly should be returned should the marriage end..$^{59}$

As indicated, state-law customary marriages, those sanctioned and regulated by the Recognition of Customary Marriages Act, are now sui generis marriages with western and African features. Bearing this in mind, the economic significance of the bridewealth should be developed: The time has perhaps come that, along the lines of Roman law, bridewealth agreements should be formalised and reduced to writing, indicating exactly how it should be utilised when the marriage ends. Further, it may be appropriate to restrict the bridewealth holder's rights to use the bridewealth so that it is kept intact, should the woman and her children need it at a later stage. 


\section{Bridewealth and the validity of a customary marriage}

In accordance with the Recognition of Customary Marriages Act, the requirements for a valid customary marriage are that the parties agree to be married to each other under customary law, that they are above eighteen, and that "the marriage must be negotiated and entered into or celebrated in accordance with customary law". ${ }^{60}$ The Act does not explicitly mention bridewealth or the handing over of the bride as a part of the marriage negotiations or as requirements for validity. This has caused much uncertainty in legal practice regarding the status of bridewealth (and the ceremonial handing over of the bride) vis-à-vis the validity of a customary marriage.

The transfer of marriage goods and the fact that the woman is physically transferred to her husband's group upon marriage are common to marriages of all Southern African Bantuspeakers. Yet, in traditional customary law, the actual transfer of bridewealth was not an essential requirement for a valid marriage. In fact, it was even possible to waive the right to the transfer of the bridewealth altogether. It was nevertheless necessary for a valid marriage that there had to be at least an agreement to deliver bridewealth. ${ }^{61}$

Importantly, marriage in traditional African law was an ongoing process that joined two families together. ${ }^{62}$ The obligations in terms of the marriage agreement were of a continuing nature. These included the family of the husband's ongoing obligation to take care of the woman and her children. In turn, the woman had the ongoing obligation to provide her services and earnings to her husband and his family. Therefore, if the bridewealth was not delivered or not delivered in full, the obligation did not become extinguished. Where the woman joined her new family before bridewealth had been transferred at all or in full, the husband or his family group remained liable to perform.

It follows naturally that neither a spouse's inability to procure children, nor the refusal to transfer marriage goods, was a ground to dissolve the marriage. The respective families had to provide substitutes to rectify the inability to have children. ${ }^{63}$ In addition, death did not dissolve a marriage: the deceased spouse's family of origin merely provided a substitute. If a widow wanted to remarry, her family had to return the bridewealth to her late husband's family. The new prospective husband would again transfer marriage goods to the woman's family of origin and it would have served the same function of securing proper care of her and her children by her new husband and his group. Similarly, her father would again be obliged to take care of her if necessary during the subsistence of the marriage or after its termination.

The intention of the Law Reform Commission when it drafted the Recognition of Customary Marriages Act was clear: it did not regard bridewealth as an essential requirement for a valid customary marriage. It confirmed the fact that customary marriages were flexible and pragmatic ${ }^{64}$ and that even in traditional law, customary ceremonies could be shortened or combined with civil-law marriage ceremonies or even completely ignored.$^{65} \mathrm{It}$ recommend that the handing over of the bride and bridewealth should be regarded as optional. ${ }^{66}$ In its Report the Law Reform Commission stated that "it seems sensible to regard the legal effect 
of giving lobolo [bridewealth] as a form of evidence, albeit weighty evidence, of the parties' intention to contract a customary form of marriage". ${ }^{67}$ The Cape High Court confirmed this view in its decision in Mabuza v Mbatha ${ }^{68}$ when it held that no traditional marriage custom should be elevated into something so indispensable that without it there could be no valid customary marriage.

Notwithstanding, a perusal of the South African Law Reports shows that generally the courts regard bridewealth and the traditional handing over of the bride to her new family as necessary requirements for a valid customary marriage. Moreover, the courts tend to treat these customary practices on an ad hoc basis and there appears to be little consistency in their decisions regarding their role in customary marriages. The result is that numerous customary-law marriages have been denied validity because either or both of these two traditional features were absent. In addition, the uncertainty has also opened an avenue for opportunistic parties to marriage disputes to use and manipulate these customs to their advantage to prove or disprove the existence of a marriage. ${ }^{69}$

A recent case in point is the decision in Eunice Xoliswa Ngema $v$ Sifiso Raymond Debengwa ${ }^{70}$ where the North Gauteng High Court found that there was no valid customary marriage because the plaintiff had not been ceremoniously handed over to the defendant's family and the defendant had not consented to the marriage, as he claimed. The Court reached this decision despite the fact that the parties were ad idem that bridewealth had been negotiated and had been paid in full. Moreover, they agreed that a celebration had taken place at the bridewealth negotiations where blankets and scarves were ceremoniously put on some of the women present; ${ }^{71}$ and they agreed that the plaintiff had lived with the defendant for a number of years. Both the High Court and the Supreme Court of Appeal denied the plaintiff leave to appeal.

There are interesting resemblances in traditional African marriages and marriages in classical Roman law. The requirements for a valid Roman marriage were that the parties had to be of the right age and status to marry each other; and that both of them and the persons under whose authority they were had consented to the marriage. ${ }^{72}$ No formalities were required to conclude a iustum matrimonium. ${ }^{73}$ However, the ceremonial delivery of the bride to her husband's home, deductio in domum mariti, while not a legal requirement for a valid marriage, was a visible sign and, as such, proof that the marriage had in fact taken place. The deductio in domum was regarded as a public expression of the consent of the parties and their affectio maritalis. ${ }^{74}$ The marital affection was indicative of the parties' intention to live as husband and wife and distinguished the relationship between them from mere concubinage. ${ }^{75}$

Likewise, payment of dowry was proof that the parties had reached an agreement to live together as husband and wife. ${ }^{76}$ Neither dowry nor dowry documents (tabulae dotales) were legal requirements ${ }^{77}$ for a valid marriage.

Scaevola's response in D. 24.1.66pr. clearly shows that a marriage was concluded the moment consensus was reached and that the time of the ceremonial procession to the groom's house and of the signing of the dotal documents were irrelevant to this question: 
Seia, when about to marry Sempronius on a certain day, before she was conducted to his house, and before the marriage contract was signed, gave him a certain number of aurei. I ask whether this donation is valid. I answered that strict attention should not be paid to the time, that is, whether the donation was made before she was conducted to his house, or before the marriage contract was signed, as very frequently this is done after the marriage has been celebrated; for unless the donation was made before the marriage was contracted, which is understood to have been done by the consent of the parties, it will not be valid. ${ }^{78}$

Importantly, while there could be a marriage without dowry, dowry could not exist without a marriage. ${ }^{79}$ Ulpian thus states in D. 23.3.3: "The term dowry does not apply to marriages which are void, for there cannot be a dowry without marriage. Therefore, where the name of marriage does not exist, there is no dowry." ${ }^{80}$

The significance of the Roman dowry was wide-ranging. ${ }^{81}$ As in African customary law, it was regarded as a gift to strengthen the bond between the families of the bride and the groom; it was a "symbolic expense" towards the proper celebration of the union; ${ }^{82}$ it served to assist the newlyweds in setting up their home; it allowed the woman to share in her family's estate even though she formed part of her husband's family; and it was a "groomprice" aimed at inducing the grooms parents to agree to the marriage.

The position regarding dowry that obtained in classical law, did not change substantially in late Roman law, at least not in the eastern Empire. Attempts were made in the western Empire to make dowry an essential prerequisite for a valid marriage when Valentinianus III determined that children born from a marriage that was not accompanied by the usual marriage ceremonies, would be illegitimate. ${ }^{83}$ Interestingly, in this rescript celebration of the marriage was linked to honourability: honesta celebratione matrimonii.

Some two years later, in AD 428, Emperor Theodosius II of the East rejected this law and in a rescript confirmed the classical Roman law position that a valid marriage rested on consent only and that dowry and marriage ceremonies were not prerequisites for it:

"If instruments of prenuptial gifts or dowries should be lacking and if the solemn procession and other wedding ceremonies should be omitted, no person shall suppose that on this account a marriage otherwise legally entered into shall lack validity or that the rights of legitimacy can be taken away from children born of such a marriage, when the marriage is contracted by persons of equally honourable status, when it is precluded by no law, and when it is confirmed by the consent of the parties and the reliable testimony of friends etc.". 84

However, in the West, the position remained uncertain and in 458, Emperor Majorian again issued a decree that made dowry a prerequisite for a valid marriage. His main concern appears to have been the welfare of the children and the protection of their "due benefits". He determined that "[g]irls and the parents of girls and any persons who are going to marry shall know that if they should be joined in marriage without a dowry, they must be branded with the stigma of infamy and that neither will the union be adjudged a marriage nor will legitimate children be born from them". ${ }^{85}$ In AD 463, the western Emperor, Severus, repealed this law, but the notion that dowry was a prerequisite for a valid marriage was taken up by Pope Leo and by the Germanic codes of the West. ${ }^{86}$ 


\section{Conclusion}

The legislative regulation of customary marriages in South Africa has deprived them of their flexibility and adaptability, characteristics of the non-specialised legal system. These marriages have become sui generis marriages with both western and African features. Many of the equitable attributes of the traditional customary marriage that served to protect women and children have disappeared. This article focused on two specific problem areas of bridewealth: its role in the formation of a valid customary marriage, and its maintenance function. The central question it considered was whether Roman law could provide new perspectives on the problem areas of bridewealth in African customary law.

Numerous similarities were identified in the role and function of bridewealth in African marriage customs and of the Roman dowry. And, indeed, there are some lessons to be learnt from Roman law, not least of all from the simple principle that while there can be a marriage without dowry, dowry cannot exist without a marriage. The Recognition of Customary Marriages Act confirmed the traditional African law position that there can be a marriage without bridewealth, as long as bridewealth was negotiated. ${ }^{87}$ But can bridewealth exist without a marriage? This is a question that often arises in South African courts. Following the elementary rule of Roman law, the answer should be "no".

However, this principle aligns also with African marriage culture. In traditional African societies, bridewealth was sacrosanct. It had social, ritual and spiritual significance. Empirical research has confirmed that this time-honoured institution is still an important facet of African marriages today, even in urban areas. Despite criticism against the institution, traditional sentiments still obtain. If "Lobola ... is the framework that people use to express and to bring about complicated changes in terms of relationships and deep changes in terms of emotional realities, values, attitudes and concepts", if it is still regarded as "the language that the ancestors understand and bless", ${ }^{88}$ why would families come together and agree on, or transfer, bridewealth with all its wider social and religious implications if they had not in fact consented to a marriage? As such, bridewealth should be regarded as strong evidence that a marriage exists. And if in addition the woman has joined her husband's family, whether ceremoniously or not, there should be no doubt that a marriage had been concluded.

It is unfortunate that the maintenance function of bridewealth has largely dissappeared. This function should be restored. Such great store did the Romans set in the maintenance function of dowry, that by the time of Justinian maintenance had become its primary function, and the husband's rights in the dowry had become so curtailed that he was its owner merely in name. Following Roman law, the time has perhaps come that rules be formalised to restrict the rights of the bridewealth holder (the family of the bride) to the bridewealth, thus keeping it secure for future use by the woman and her children, should the need arise. 
* Professor, Department of Jurisprudence, School of Law, University of South Africa; vniekgj@unisa.ac.za. I thank the University of South Africa for their financial assistance that enabled me to conduct research at the Institute of Advanced Legal Studies in London, UK. Opinions and conclusions are those of the author and not the University of South Africa.

${ }^{1}$ See, e.g., the description of the bridewealth custom amongst the Khoi by De Grevenbroek, a seventeenthcentury official of the Dutch-East India Company at the Cape of Good Hope: Virginem nubilem viro tempestivam à parentibus procus ex vicino, et nunquam eodem quo amasia nata vico oriundus, instituto probabili, quanto potest minime mercatur ... (When a girl becomes of marriageable age and ripe for a husband, a suitor from a neighbouring village, but never from the same one as his beloved (an excellent institution) purchases her from her parents at the lowest price for which he can get her...): see Johannes Gulielmus de Grevenbroek Gentis Africanae circa Promontorium Capitis Bona Spei Vulgo Hottentotten Nuncupatae Descriptio (1695) (translated and annotated in 1. Schapera \& B. Farrington (eds.) The Early Cape Hottentots (Cape Town, 1933)) at 198, 199. In the decision in Kaba v. Ntela 1910 T.S. 964 at 967, the Court stated that according to s. 24 of Law 3 of 1876 (Zuid-Afrikaansche Republiek), in the interest of morality, the buying of wives and polygamy amongst the coloured people were not recognized. (" $[t]$ ot bevordering der zedelijkheid wordt het aankoopen van vrouwen of veelwijverij onder de kleurlingen in deze Republiek door de wetten des lands niet erkend"). The Court further stated that accordingly, an African customary marriage was against the "general principles of civilisation, because of its polygamous character", was void and "from the narrow point of view of the law an illicit and ... an immoral cohabitation" (at 970).

2 State-law pluralism refers to a situation where different legal systems are officially recognised and applied. Within a paradigm of deep legal pluralism, which also prevails in South Africa, multiple legal systems, which are not recognised by the state, apply unofficially.

${ }^{3}$ The Roman-Dutch law that was brought to South Africa during the seventeenth century, when the Dutch established a refreshment station at the Cape of Good Hope, was influenced by English common law from the eighteenth century onwards and has been developed over the years by local legislation and judicial precedent.

${ }^{4}$ South African Law Reform Commission Harmonisation of the Common Law and the Indigenous Law (Customary Marriages) Project 90, Report (Aug. 1998).

${ }^{5}$ Technically, the harmonisation of laws involves removing conflicting features of the relevant legal systems, but preserving each legal system's distinct characteristic features. That ensures that the legal systems continue to apply as separate legal systems.

${ }^{6}$ Act 20 of 1998.

${ }^{7}$ Polygyny is recognised only where both marriages are customary marriages.

${ }^{8}$ See Rita-Marie Jansen \& Alet Ellis "The South African common law and lobolo - another perspective" (1999) Fundamina (editio specialis) 114-131 at 129.

${ }^{9}$ Historically, "bridewealth" and "dowry" were used interchangeably in both literature and case law. E.g., in a discussion of Malgas v. Gakawu in "Native customs and the Colonial courts" (1891) 8 Cape Law J. 37-41 at 39, the author observed that, "to impose upon the Courts of a civilised Government the duty of trying cases relating to 'dowry,' in the widest sense of the term, would be the deliberate recognition of polygamy, and also the indefinite postponement of the time when native women shall be released from their present level of almost hopeless degradation". In Ngqobela v. Sihele (10 S.C. 346 at 352), the Court declared: "[I]f, by native custom, 'dowry' cattle is paid to the woman's father on condition 
that upon her refusing to cohabit with the man any longer the latter shall be entitled to claim the cattle from the father, the claim cannot be enforced by our courts. In law there is a par delictum, and the claimant cannot prevail over the possessor." Today, too, some courts still use the terms interchangeably: see Chali v Rasello (683/2011) [2011] ZAFSHC 121; Leboho v Premier of Limpopo Province (37898/07) [2011] ZAGPPHC 22; and Southon v Moropane (14295/10) [2012] ZAGPJHC 146 all available at http://www.saflii.org (accessed 24 Jul. 2017). In the latter case in par. [43] the Court stated: "With the payment of 'pula molomo', the man was formally ushered into the bride's home. He testified that 'pula molomo' was the 'initial lobola' and the beginning of the dowry which will be counted, as part of the lobola [bridewealth]." Section 1(iv) of the Recognition of Customary Marriages Act 120 of 1998 defines "lobolo" as: "the property in cash or in kind, whether known as lobolo, bogadi, bohali, xuma, lumalo, thaka, ikhazi, magadi, emabheka or by any other name, which a prospective husband or the head of his family undertakes to give to the head of the prospective wife's family in consideration of a customary marriage". In South Africa, "lobolo" has become the common term that denotes bridewealth.

${ }^{10}$ Bruce W. Frier "The Roman Dowry. Some Economic Questions" available at http://www.law.umich.edu/centersandprograms/lawandeconomics/workshops/Documents/Paper\% 2012.Frier.Roman\%20Dowry-\%20Some\%20Economic\%20Questions.pdf. (accessed 26 Jul. 2017) at 4, notes that unlike bridewealth that is a social institution of "societies that are evolving from primitivism to the early stages of modernism", dowry occurs in "far larger, more populous, richer, and more complex" societies; cf., also, Diane Owen Hughes "From bride price to dowry in Mediterranean Europe" (1978) $3 \mathrm{~J}$. of Family History 262-296 at 263.

${ }^{11}$ Her family of origin retains the plenary guardianship. See, generally, A.C. Myburgh "Law and Justice" in W.D. Hammond-Tooke (ed.) The Bantu-speaking Peoples of Southern Africa (London, 1974) at 304; J. Church "'Lobolo': A critical evaluation" in A.J.G.M. Sanders (ed.) Southern Africa in Need of Law Reform (Durban, 1981) at 28.

${ }_{12}$ G.M.B. Whitfield South African Native Law (Cape Town, 1948) at 525.

${ }^{13}$ A.C. Myburgh Papers on Indigenous Law (Pretoria, 1985) at 111; Joan Church Marriage and the Woman in Bophuthatswana: An Historical and Comparative Study (unpublished doctoral thesis, Pretoria, 1989) at 36-37; for a detailed discussion of a traditional Pedi marriage, see H.O. Mönnig The Pedi (Pretoria, 1978)129ff.

${ }^{14}$ See C. 5.4.9; Bruce W. Frier \& Thomas A.J. McGinn A Casebook on Roman Family Law (Oxford, 2004) at 29, 39-40, 47; Susan Treggiari Roman Marriage (Oxford, 1991) at 11; Judith Evans Grubbs Women and the Law in the Roman Empire. A Sourcebook on Marriage, Divorce and Widowhood (London, 2002) at 92; J.L. Barton "Marriage in Roman law" (1977) 52/53 Law \& Justice - The Christian Law Review 923 at 9.

${ }^{15}$ D. 1.1.1.3: lus naturale est, quod natura omnia animalia docuit: nam ius istud non humani generis proprium, sed omnium animalium, quae in terra, quae in mari nascuntur, avium quoque commune est. Hinc descendit maris atque feminae coniunctio, quam nos matrimonium appellamus, hinc liberorum procreatio, hinc educatio ...; and cf., further D. 23.2.1; D. 50.16.220.3; Evans Grubbs (n. 14) at 81. This reminds of the spiritual aspect of the bridewealth institution in African law, which links the institution with the ancestors: see the references at $n .22$ below.

${ }^{16}$ On the lex lulia de maritandis ordinibus, promulgated in $18 \mathrm{BC}$ (succeeded by and included in the lex Papia Poppaea in AD 9), see Treggiari (n. 14) at 60-80; Mary R. Lefkowitz \& M.B. Fant "Legal status in the Roman world" in Women's Life in Greece and Rome in pars. 120-123, available at http://www.stoa.org/diotima/anthology/wlgr/wlgr-romanlegal120.shtml\#pass121 (accessed 16 Aug. 2017); Evans Grubbs (n. 14) at 83 ff. 
${ }^{17}$ Pomponius lib. xv ad Sabinum: Dotium causa semper et ubique praecipua est: nam et publice interest dotes mulieribus conservari, cum dotatas esse feminas ad subolem procreandam replendamque liberis civitatem maxime sit necessarium.

${ }^{18} \mathrm{Cf}$., Frier (n. 10) at 5, who notes that there is the perception that in "relatively primitive 'tribal' societies, women usually have an economic value of their own through their input into agricultural production; hence their families receive a bride price in compensation for the loss of a producer".

${ }^{19}$ This was the general view in colonial Africa. For a brief survey of the different interpretations of this cultural institution in sub-Saharan Africa, see Stanley J. Tambiah "Bridewealth and dowry revisited: The position of women in sub-Saharan Africa and North India" (1989) 30(4) Current Anthropology 413-435 at $414 \mathrm{ff}$.

${ }^{20}$ T.C. Sandars, The Institutes of Justinian (London, 1934) at 333; W.W. Buckland A Text-Book of Roman Law (Cambridge, 1963, 3rd. ed. Peter Stein) at 457-458. In classical law, this obligation was enforceable by a condictio. It fell into disuse when Theodosius II made enforceable any informal promise of a dowry: C.Th. 3.13.4 and the interpretatio in Clyde Pharr The Theodosian Code and Novels and the Sirmondian Constitutions (New York, 1959; 1969 repr.) at 76; This oral agreement was in later years documented in the tabula dotalis, which was ceremonially ratified at the wedding ceremony: Treggiari (n. 14) at 165.

${ }^{21}$ This facet of bridewealth is described by De Grevenbroek (n. 1) at 198, 199: ... forte etiam quo pacis, societatis et concordiae studia, et commercii nervi cum finitimis, hoc sacro foedere, jugali vinculo et matrimoniali capistro fidelius stringantur, et nuptiis alligati arctius coalescant ... (... the intention may also be that peace, harmony and concord, and the threads of friendly dealing may be drawn tighter by this sacred treaty, pledge of union, and matrimonial bond; that the marriage may be a link to bind them more closely to one another ...)

${ }^{22}$ For an overview of the various anthropological and legal interpretations of the meaning of bridewealth in African culture, see N.J.J. Olivier, N.N.J. Olivier (Jnr.) \& W.H. Olivier Die Privaatreg van die SuidAfrikaanse Bantoetaalsprekendes (Durban, 1989) at 98ff. See, further, Whitfield (n. 12) at 523; Eleanor Preston-Whyte "Kinship and marriage" in Hammond-Tooke (n. 11) at 187f., M.W. Prinsloo, G.J. van Niekerk \& L.P Vorster "Current research on lobolo by means of a questionnaire" (1997) 30 De Jure 98117 at 98-99; M.W. Prinsloo, G.J. van Niekerk \& L.P Vorster "Perceptions of the law regarding, and attitudes towards, lobolo in Mamelodi and Atteridgeville" (1998) 31 De Jure $72-92$ at 74 (hereafter Prinsloo, Van Niekerk \& Vorster "Perceptions"); Jansen \& Ellis (n. 8) at 114-115; Church (n. 11) at 33; Dorrit Posel \& Stephanie Rudwick "Marriage and ilobolo [bridewealth] in contemporary Zulu society" (2014) 57(2) African Studies Review 51-72 at 54 (hereafter Posel \& Rudwick "Contemporary Zulu society"); Stephanie Rudwick \& Dorrit Posel "Zulu bridewealth (ilobolo) and womanhood in South Africa" (2015) Social Dynamics: A J. of African Studies 1-18 available at $h t t p: / / d x . d o i . o r g / 10.1080 /$ 02533952.2015.1060683 at 1-2 (hereafter Rudwick \& Posel "Womanhood").

${ }^{23}$ South African Law Reform Commission (n. 4) in par. 4.3.1.2.

24 Prinsloo, Van Niekerk \& Vorster “Perceptions" (n. 22) at 81, 92.

${ }^{25}$ See the study of Rudwick \& Posel "Womanhood" (n. 22).

${ }^{26}$ Rudwick \& Posel "Womanhood" (n. 22) at 2, 3.

${ }^{27}$ Idem at 5-7.

${ }^{28} \mathrm{~A}$ double marriage occurs where a man and a woman conclude both a customary and a civil marriage with each other. 
${ }^{29}$ Rudwick \& Posel "Womanhood" (n. 22) at 1; Also Papa I.P. Maithufi "The requirements for validity and proprietary consequences of monogamous and polygynous customary marriages in South Africa: Some observations" (2015) De Jure 261-279 at 278 observes that bridewealth usually forms part of civil marriages.

${ }^{30}$ M.W. Prinsloo, G.J. van Niekerk \& L.P Vorster "Knowledge and experience of lobolo in Mamelodi and Atteridgeville" (1997) 30 De Jure 314-330 at 325.

${ }^{31}$ Rudwick \& Posel "Womanhood" (n. 22) at 2.

32 Ibid. (emphasis added).

${ }^{33}$ See D. 23.3.3.

${ }^{34}$ See Kaser Das römische Privatrecht vol. 1 (Munich, 1971) at 59; Treggiari (n. 14) at 34; Evans Grubbs (n. 14) at 19-20; Thomas A.J. McGinn Prostitution, Sexuality and the Law in Ancient Rome (Oxford, 1998) at 153; Annelize Jacobs "Maritus v Mulier: The double picture in adultery laws from Romulus to Augustus" (2015) 21(2) Fundamina 276-288 at 286. Andrew T. Bierkan, Charles P. Sherman \& Emile Stocquart "Marriage in Roman law" (1907) The Yale Law Review 303-327 at 317 note: "In juridical language, the words matrona or materfamilias had a clear and precise meaning, exacting a two-fold condition for the wife; first, to have had a Roman citizen for a father; second, to have maintained an honourable and pure life, the dignity which her origin gave to her."

${ }^{35}$ See, e.g., D. 3.1.1.5; C. 2.12.21; D. 26.10.1.7.

${ }^{36}$ (n. 14) at 323.

${ }^{37}$ Trin. 691.

${ }^{38}$ See, e.g., C. 5.5.7.2; Nov.Marc. 4.2; C. 5.27.

39 See, generally, Gardiol van Niekerk \& Duard Kleyn “Honeste vivere: Ulpian's praecepta iuris as manifested in the Roman law of marriage" (2016) 2 Studia iurisprudentia universitas Babeş-Bolyai iurisprudentia available at $h t t p s: / / s t u d i a . l a w . u b b c l u j . r o /(a c c e s s e d 14$ Aug. 2017).

${ }^{40}$ Treggiari (n. 14) at 329; for a discussion of the powers of the uxor dotata as expressed in the literature, see further, idem at 330-331. D. 48.5.12(11).3 illustrates the relative power of a large dowry when the wife's adultery is overlooked for fear of loosing it: Papinianus lib. singulari de adulteriis: Socer cum nurum adulterii accusaturum se libellis praesidi datis testatus fuisset, maluit accusatione desistere et lucrum ex dote magis petere. Quaeritur, an huiusmodi commentum eius admitti existimes. Respondit: turpissimo exemplo is, qui nurum suam accusare instituisset, postea desistere maluit contentus lucrum ex dote retinere tamquam culpa mulieris dirempto matrimonio: quare non inique repelletur, qui commodum dotis vindictae domus suae praeponere non erubuit. (A father-in-law who, in a written accusation filed with the Governor, stated that he accused his daughter-in-law of adultery, preferred to abandon the accusation and obtain her dowry. The question arises whether you think that a scheme of this kind should be permitted. The answer was, that it is a very dishonourable example for a person, after he has brought an accusation against his daughter-in-law, to desire to abandon it, and remain content with the profit obtained from her dowry, as the marriage was dissolved through the fault of the woman. Wherefore he will not be unjustly barred who was not ashamed to prefer the advantage of the dowry to avenging the honour of his house.)

${ }^{41}$ Richard P. Saller Patriarchy, Property and Death in the Roman Family (Cambridge, 1997) at 221, 223224.

${ }^{42}$ Participants in the study of Rudwick \& Posel "Womanhood" (n. 22) at 9 opined that bridewealth did not necessarily safeguard the personal security of the wife. It could in fact have the opposite result: trapping the wife in an abusive relationship because her family of origin was unable to return the bridewealth. 
43 J.B. Hartman Aspects of Tsonga Law (Pretoria, 1991) at 35ff; Olivier et al. (n. 22) at 98ff. J. Van Tromp Xhosa Law of Persons: A Treatise on the Legal Principles of Family Relations among the Ama Xhosa (Cape Town, 1948) at 48, points out that the bridewealth does not serve as security for the maintenance of the wife and children by her family of origin in case of ill-treatment by her husband, because, in accordance with Xhosa law, the husband's family has to pay a fine of one beast to her family of origin for the ill-treatment. It must, however, be borne in mind that the wife may still choose not to return to her husband. In such a case, her family will return only a portion of the bridewealth. See, also, Marissa Herbst \& Willemien du Plessis "Customary law v common law marriages: A hybrid approach in South Africa" (May 2008) 2.1 Electronic J. of Comparative Law, available at http://www.ejcl.org (accessed 23 Aug. 2017)

44 Victoria Hosegood, Nuala McGrath \& Tom Moultrie "Dispensing with marriage: Marital and partnership trends in rural KwaZulu-Natal, South Africa 2000-2006" (2009) 20 Demographic Research 279-312 available at http://www.demographic-research.org (accessed 29 Aug. 2017) at 283ff., describes the historical regulation of the institution in KwaZulu Natal from the nineteenth century and the legislative fixing of the amount of bridewealth which lead to its commercialization; see, also, Posel \& Rudwick "Contemporary Zulu society" (n. 22) at 55-56, 62ff.

${ }^{45}$ Posel \& Rudwick "Contemporary Zulu society" (n. 22) at 64; Sandra Burman (1991) 7 "Capitalising on African strengths: Women, welfare, and the law" South African J. on Human Rights 215-221 at 220 observes that the woman's family of origin nowadays regards the bridewealth as a "cash bonanza".

${ }^{46}$ See South African Law Reform Commission (n. 4) in pars. 4.3.1.8-10; Posel \& Rudwick "Contemporary Zulu society" (n. 22) at 55; see, also, Rudwick \& Posel "Womanhood" (n. 22) at 9; Burman (n. 45) at 220.

47 Jansen \& Ellis (n. 8) at 130. Burman (n. 45) at 219-221, too, suggests that bridewealth should be reconsidered as a source of funding to contribute to the maintenance of the customary wife and children. However, her solution moves completely away from the traditional maintenance function of bridewealth. She proposes the establishment of a so-called "Bridewealth Fund", similar to a Retirement Annuity Fund or a Trust Fund, to which the groom and his family would contribute a single lump sum, or make regular contributions.

${ }^{48}$ See ss. 1 (i) and 8 (i) of the Act.

${ }^{49}$ See Burman (n. 45) at 216. At 217; she observes that international research has shown that default on maintenance payments is not limited to South Africa, but occurs in numerous other wealthier countries.

${ }^{50}$ Section 8(4)(e).

${ }^{51}$ Cf., also, Jansen \& Ellis (n. 8) at 130; Thulani Nkosi "The ending of a customary marriage. What happens to the ilobolo?" (2013) De Rebus 36-39.

52 The free marriage came into existence through consent. It was a social institution in pre-classical and classical law and there were no prescribed legal formalities. Marriage became a legal institution only in post-classical law: see D. 23.2.1; D. 25.2.1; D. 42.1.52; Kaser 1 at 72-73, 310-311; Kaser/Wubbe Romeins Privaatrecht (Zwolle, 1967) at 278; Barry Nicholas An Introduction to Roman Law (London, 1962) at 80.

53 The husband's rights in the dowry were complicated: in this regard, see the discussion of Buckland (n. 20) at 108; Frier (n. 10) at 8ff; Evans Grubbs (n. 14) at 95-97. By the time of Justinian, the husband's ownership of the dowry was in practice restricted to a right to income from it for the duration of the marriage: see Nicholas (n. 52) at 88-90. 
${ }^{54}$ Dowry received legal recognition for the first time in 230 B.C: When Carvilius Ruga divorced his wife without a satisfactory explanation before the family council and without returning the dowry, his family-in-law instituted a successful action against him for the recovery of the dowry: see Suzanne Dixon "The marriage alliance in the Roman elite" (1985, Winter) J. of Family History 353-378 at 357.

${ }^{55}$ See Nov.Th. 14 and the interpretatio in Pharr (n. 20) at 498-500; cf. Evans Grubbs (n. 14) at 115-116; Dixon (n. 54) at 364.

${ }^{56}$ Buckland (n. 20) at 107.

${ }^{57}$ For a detailed exposition of the development of the rules regulating the return of dowry, see Buckland (n. 20) at 108ff; Barton (n. 14) at 15-17; Jane F. Gardner "The recovery of dowry in Roman law" (1985) 35(2) Classical Quarterly 449-453 at 449ff. It should be borne in mind that return of the dowry was further important because it secured the possibility of a second marriage.

${ }^{58}$ The Recognition of Customary Marriages Act is silent on the fate of the bridewealth when the marriage ends. Nevertheless, the courts follow the traditional customary-law rules. See, generally, Olivier et al. (n. 22) at 193ff. for the customary-law rules in this regard. The question whether bridewealth is returned, depends on the circumstances. See, e.g., Sila v Masuku 1937 NAC (N \& T) 121; Matlala v Tompa 1951 NAC (N-E) 404; Nkambule v Linda 1951 (1) SA 377 (A); Thembisile and another v Thembisile and another 2002 (2) SA 209 (T); Netshituka v Netshituka and Others 2011 (5) SA 453 (SCA). See, also, Herbst \& Du Plessis (n. 43) at 11; Nkosi (n. 51) at 36-39.

59 J.A. Crook Law and Life of Rome (Ithaca, NY, 1984) at 104-106; Judith Evans Grubbs Law and Family in Late Antiquity (Oxford, 1999) at 55, 145, 226-228; Barton (n. 14) at 15-17.

${ }^{60}$ See s. 3(1) of the Act.

${ }^{61}$ See South African Law Reform Commission (n. 4) in par. 4.3.3.2; Church (n. 11) at 30-31; Posel \& Rudwick "Contemporary Zulu society" (n. 22) at 54; Maithufi (n. 29) at 266.

${ }^{62}$ This is in line with the fact that prescription does not exist in African customary law. The Tswana maxim states that "a debt does not decay" (molato ga o bôle). Thus, the obligation to pay marriage-goods does not prescribe: see Church (n. 13) at 22-23, 37; Joan Church "Betrothal and Marriage: Contractual Aspects" in Indigenous Contract in Bophuthatswana (1990) at 88-89; Church (n. 11) at 28.

63 Preston-Whyte (n. 22) at 188 and, cf., idem at 193-194.

${ }^{64}$ The flexible, adaptable nature of customary law is widely accepted: see, e.g., the Constitutional Court decisions in the seminal cases of Bhe and Others v Magistrate, Khayelitsha, and Others 2005 (1) SA 580 (CC) in pars. [45], [110]; Shilubana and Others v Nwamitwa and Others 2008 (9) BCLR 914 (CC) in pars. [35], [65]; and cf., Mayelane v Ngwenyama and Another 2013 (4) SA 415 (CC) in pars. [24](f), [25]; and see, Annika Claassens \& Geoff Budlender "Transformative constitutionalism and customary law" available at

http://www.constitutionalcourtreview.co.za/wp-content/uploads/2016/09/TransformativeConstitutionalism-and-Customary-Law-CCR-VI.pdf (accessed 28 Aug. 2017).

${ }^{65}$ See, e.g., I. Schapera Married Life in an African Tribe (Evanston, 1966) at 71ff.; Van Tromp (n. 43) at 578; Brian Allan Marwick The Swazi (London, 1940) at 121. See, further, R.T. Nhlapo Marriage and Divorce in Swazi Law and Custom (Mbabane, 1992) at 29ff. and at 65-66; South African Law Reform Commission (n. 4) in par. 4.4.7.

${ }^{66}$ South African Law Reform Commission (n. 4) in par. 4.4.10. In par. 4.3.3.6 it likened bridewealth to the "solemnization of marriages by religious rites".

${ }^{67}$ See South African Law Reform Commission (n. 4) in par. 4.3.3.6.

${ }^{68} 2003$ (4) SA 218 (C) in par. [25]. 
69 It is often averred that the goods transferred to the woman's family was merely to "open negotiations" and not intended as bridewealth. See, e.g., Southon $v$ Moropane (n. 9).

70 Unreported case no $2011 / 3726$ of $14 / 62016$.

71 In pars. [8] and [17].

72 See D. 23.2.2.: Paul lib. 35 ad ed.: Nuptiae consistere non possunt nisi consentiant omnes, id est qui coeunt quorumque in potestate sunt.

73 In D. 23.2.1, Modestinus describes the lawful Roman marriage as "the union of a man and a woman, forming an association during their entire lives, and involving the common enjoyment of divine and human privileges".

${ }^{74}$ Blume ad C. 5.4.9 (Fred H. Blume Annotated Justinian Code, available at http://www.uwyo.edu/lawlib/blume-justinian/); D. 23.2.5.; Treggiari (n. 14) at 166-167.

75 On affectio maritalis, see D. 24.1.32.13; D. 39.5.31pr.; cf., also, Treggiari (n. 14) at 54-57, 448-449; Frier \& McGinn (n. 14) at 49-53.

${ }^{76}$ Alan Watson The Spirit of Roman Law (Athens, London, 2008) at 10, 70.

77 In D. 39.5.31pr. Papinian responded ... An autem maritalis honor et affectio pridem praecesserit, personis comparatis, vitae coniunctione considerata perpendendum esse respondi: neque enim tabulas facere matrimonium. See, also, C. 5.4.9.; Buckland (n. 20) at 107; Judith Evans Grubbs "Marriage contracts in the Roman Empire" in Lena Larsson Lovén \& Agneta Strömberg (eds.) Ancient Marriage in Myth and Reality (New Castle upon Tyne, 2010) 78-101 at 78-82.

${ }^{78}$ Seia Sempronio cum certa die nuptura esset, antequam domum deduceretur tabulaeque dotis signarentur, donavit tot aureos: quaero, an ea donatio rata sit. Non attinuisse tempus, an antequam domum deduceretur, donatio facta esset, aut tabularum consignatarum, quae plerumque et post contractum matrimonium fierent, in quaerendo exprimi: itaque nisi ante matrimonium contractum, quod consensu intellegitur, donatio facta esset, non valere.

${ }^{79}$ D. 23.3.3; cf., also, D. 23.3.39.1; C.J. 5.3.20.2: “For as dowry becomes such on account of marriage, and there is no dowry without a marriage, although marriage may be entered into without dowry ...)

${ }^{80}$ Ulpianus lib. 63 ad ed. Dotis appellatio non refertur ad ea matrimonia, quae consistere non possunt: neque enim dos sine matrimonio esse potest. Ubicumque igitur matrimonii nomen non est, nec dos est.

81 Vijayendra Rao "The economics of dowries in India," in Kaushik Basu (ed.) Oxford Companion to Economics in India (2007) at 118-121; Frier (n. 10) at 6 describes it as "more than just an economic institution; it functions also as a richly-textured social institution ...".

82 In African customary law the bride's family used it towards hosting the wedding: see South African Law Reform Commission (n. 4) in par. 4.3.1.8.

${ }^{83}$ C.Th. 4.6.7: Impp. Theodosius et Valentinianus ... Naturalium his nomen sancimus imponi, quos sine honesta celebratione matrimonii procreatos legitima coniunctio fuderit in lucem; servos autem ex ancillae utero ipso iure generari patet, quamvis per vim naturae ne illis quidem possit naturalium nomen auferri. (We sanction that the name of natural [illegitimate] children shall be placed upon those who have been begotten and brought into this world as the result of a lawful union without an honourable performance of the marriage ceremony ...) tr. Pharr (n. 20); Evans Grubbs (n.14) at 90-94, 114-115.

${ }^{84}$ Impp. Theodosius et Valentinianus ... Si donationum ante nuptias vel dotis instrumenta defuerint, pompa etiam aliaque nuptiarum celebritas omittatur, nullus aestimet, ob id deesse recte alias inito matrimonio firmitatem, vel ex eo natis liberis iura posse legitimorum auferri, si inter pares honestate personas, nulla lege impediente, fiat consortium, quod ipsorum consensu atque amicorum fide firmatur etc.; also C.J. 5.4.22. 
85 Nov.Mar. 6.9: Et quia studiose tractatur a nobis utilitas filiorum, quos et numerosius procreari pro Romani nominis optamus augmento et procreatis conpetentia commoda perire non patimur, hoc necessario putavimus praecavendum, ut marem feminamque iungendos copula nuptiali par condicio utrimque constringat, id est ut numquam minorem quam exigit futura uxor sponsaliciam largitatem dotis titulo se noverit conlaturam, scituris puellis ac parentibus puellarum vel quibuscumque nupturis ambos infamiae maculis inurendos, qui fuerint sine dote coniuncti, ita ut nec matrimonium iudicetur nec legitimi ex his filii procreentur. See, further, the discussion by Evans Grubbs (n. 14) at 119.

${ }^{86}$ See Evans Grubbs (n. 59) at 302; Hughes (n. 10) at 265ff.

${ }^{87}$ Church (n. 13) at 46; Prinsloo, Van Niekerk \& Vorster "Perceptions" (n. 22) at 78, 79.

${ }^{88}$ South African Law Reform Commission (n. 4) in par. 4.3.2.7. 